\title{
DECYZJA ADMINISTRACYJNA JAKO FORMA SPRAWOWANIA NADZORU NAD UCHWAŁAMI ORGANÓW STANOWIĄCYCH INSTYTUTU BADAWCZEGO
}

\section{Wstęp i zagadnienia metodologiczne}

Instytutem badawczym jest państwowa jednostka organizacyjna, wyodrębniona pod względem prawnym, organizacyjnym i finansowym, która prowadzi badania naukowe i prace rozwojowe ukierunkowane na ich wdrożenie i zastosowanie w praktyce ${ }^{1}$. Instytut badawczy nabywa osobowość prawną z chwilą wpisania go do Krajowego Rejestru Sądowego ${ }^{2}$. Wpis taki ma charakter konstytutywny ${ }^{3}$. Instytut posiada prawo używania okrągłej pieczęci z wizerunkiem godła Rzeczypospolitej Polskiej i nazwą instytutu $\mathrm{w}$ otoku ${ }^{4}$. Status prawny instytutów badawczych, jako państwowych osób prawnych, jest wyrazem przynależności sfery nauki i prowadzenia badań naukowych do zadań państwa ${ }^{5}$.

Przedmiotem niniejszego opracowania jest z jednej strony prezentacja i charakterystyka instytutów badawczych oraz kompetencji ich organów w warstwie normatywnej, z drugiej zaś analiza założeń nadzoru nad działalnością uchwałodawczą rad naukowych instytutów jako organów stano-

* Dr, Uniwersytet Jana Kochanowskiego w Kielcach; e-mail: jandytko@wp.pl.

1 Art. 1 ust. 1 ustawy z dnia 30 kwietnia 2010 r. o instytutach badawczych, Dz. U. z 2010 r. Nr 96, poz. 618 z późn. zm.; Dz. U. z 2018 r. poz. 736 (dalej u.i.b.).

2 Art. 1 ust. 2 u.i.b.

3 Zob. D. Michta, Ustawa o instytutach badawczych. Komentarz, Warszawa 2013, s. 12.

${ }^{4}$ Art. 1 ust. 3 u.i.b.

5 Zob. M. Cilak, Instytuty badawcze jako forma działalności naukowej i gospodarczej państwa - problematyka pozycji i formy prawnej, „Prawo Budżetowe Państwa i Samorządu” 2015, nr 4 , s. 75. 
wiących. W realizacji tego celu autor posługuje się nie tylko językiem prawnym, ale i prawniczym. Koncentracja wywodów znajduje swoje główne umiejscowienie $\mathrm{w}$ analizie aktu nadzoru nad uchwałami rad naukowych instytutów badawczych - decyzji administracyjnej, jako jednej z podstawowych władczych form działania administracji. Systematyka opracowana w tej części wskazuje również, że w polu badawczym znajduje się także normatywna charakterystyka systemu weryfikacji decyzji nadzorczej, opartej na niekonkurencyjnych trybach: administracyjnym i sądowym.

\section{Pozycja prawna instytutów badawczych i ich organów}

Podstawą rozwoju każdego państwa jest postęp naukowy. Zdolność do utrzymywania efektywnego sektora badań świadczy o sile danego państwa i jego dbałości o rozwój nauki. Rolą państwa jest wspieranie takiego rozwoju w różnych przewidzianych przez prawo formach. Jedną z nich stanowią instytuty badawcze ${ }^{6}$. Charakter działalności instytutów badawczych nie jest jednoznaczny. Ich działalność wpisuje się w działalność samego państwa, z istotnym związaniem celu publicznego $\mathrm{z}$ uwarunkowaniami gospodarczymi ${ }^{7}$. Pozycja instytutu badawczego jest wyznaczana przez zakres prowadzonej przez niego działalności naukowo-badawczej, regulowanej przepisami ustrojowymi, $\mathrm{w}$ tym przepisami normującymi relacje instytutu $\mathrm{z}$ organami państwa.

Instytut badawczy stanowi inną formę organizacyjno-prawną niż przedsiębiorstwo państwowe, spółki czy stowarzyszenia, albowiem pozycja instytutu jest wyznaczona przez charakter prowadzonej przez niego działalności oraz przez przepisy regulujące jego ustrój i stosunki z organami państwa ${ }^{8}$. Podstawowa działalność instytutu badawczego koncentruje się na trzech obszarach: 1) prowadzeniu badań naukowych i prac rozwojowych; 2) przystosowywaniu wyników badań naukowych i prac rozwojowych do potrzeb praktyki; 3) wdrażaniu wyników badań naukowych i prac rozwojowych ${ }^{9}$. Wypadkową tej działalności są skonkretyzowane zadania instytutu, do których należą: 1) upowszechnianie wyników badań naukowych i prac rozwojowych; 2) wykonywanie badania i analiz oraz opracowywanie opinii i ekspertyz w zakresie prowadzonych badań naukowych i prac rozwojowych; 3) opracowywanie ocen dotyczących stanu

\footnotetext{
${ }^{6}$ Zob. tamże, s. 64.

7 Zob. tamże, s. 75.

8 Zob. tamże.

9 Art. 2 ust. 1 pkt 1-3 u.i.b.
} 
i rozwoju poszczególnych dziedzin nauki i techniki oraz sektorów gospodarki, w których wykorzystuje się wyniki badań naukowych i prac rozwojowych, w tym osiągnięć światowej nauki i techniki; 4) prowadzenie działalności normalizacyjnej, certyfikacyjnej oraz aprobacyjnej; 5) prowadzenie i rozwijanie bazy danych związanych z przedmiotem działania instytutu; 6) prowadzenie działalności w zakresie informacji naukowej, technicznej i ekonomicznej, wynalazczości oraz ochrony własności przemysłowej i intelektualnej, a także wspierającej innowacyjność przedsiębiorstw; 7) wytwarzanie $\mathrm{w}$ związku z prowadzonymi badaniami naukowymi i pracami rozwojowymi aparatury, urządzeń, materiałów i innych wyrobów oraz prowadzenie walidacji metod badawczych, pomiarowych oraz kalibracji aparatury; 8) prowadzenie działalności wydawniczej związanej z prowadzonymi badaniami naukowymi i pracami rozwojowymi ${ }^{10}$.

W zakresie działalności edukacyjnej, instytut badawczy może prowadzić studia podyplomowe i doktoranckie, związane z prowadzonymi przez instytut badaniami naukowymi i pracami rozwojowymi, jeżeli posiada uprawnienia do nadawania stopni naukowych oraz odpowiednie zaplecze i warunki materialno-techniczne. Ponadto, może organizować szkolenia i kursy dokształcające ${ }^{11}$. Może prowadzić także inną działalność, pozostającą poza sferą działalności podstawowej instytutu, która będzie odrębna pod względem finansowym ${ }^{12}$. Przykładowo, decyzją Ministra Obrony Narodowej z dnia 27 września 2016 r. ${ }^{13}$ Wojskowy Instytut Medyczny otrzymał zadanie polegające na zorganizowaniu studiów podyplomowych o kierunku „Zarządzanie i kierowanie zakładem leczniczym resortu obrony narodowej", których celem ma być pozyskanie i przygotowanie zasobu kadrowego do pełnienia kierowniczych funkcji w medycznych instytutach badawczych i podmiotach leczniczych podległych lub nadzorowanych przez Ministra Obrony Narodowej oraz jednostkach i komórkach organizacyjnych tego resortu, realizujących zadania zabezpieczenia medycznego.

Utworzenie instytutu badawczego zawsze podyktowane jest potrzebą prowadzenia działalności w określonym obszarze nauki, przy zapewnieniu niezbędnej kadry o odpowiednich kwalifikacjach oraz aparatury badawczej, laboratoryjnej, potencjału informatycznego i innych niezbędnych warunków materialno-technicznych ${ }^{14}$. Formą utworzenia instytutu jest roz-

${ }^{10}$ Art. 2 ust. 2 u.i.b.

11 Art. 2 ust. 3 u.i.b.

${ }^{12}$ Art. 2 ust. 4 u.i.b.

13 Decyzja Nr 288/MON Ministra Obrony Narodowej z dnia 27 września 2016 r. w sprawie nałożenia na instytut badawczy - Wojskowy Instytut Medyczny zadania niezbędnego ze względu na potrzeby obronności i bezpieczeństwa państwa, Dz. Urz. MON z 2016 r. poz. 163.

${ }^{14}$ Art. 4 u.i.b. 
porządzenie Rady Ministrów, wydane na wniosek ministra właściwego ze względu na planowaną działalność instytutu, złożony po zasięgnięciu opinii ministra właściwego do spraw nauki i szkolnictwa wyższego. Rozporządzenie o utworzeniu instytutu określa przedmiot i zakres działania instytutu, jego nazwę i siedzibę oraz składniki majątkowe, w tym tytuł prawny do gruntów oraz budynków i urządzeń trwale z nimi związanych ${ }^{15}$.

Działalność instytutu opiera się na statucie, który określa przedmiot i zakres działania instytutu. Statut uchwala rada naukowa, a zatwierdza minister nadzorujący, według działów administracji rządowej, w obszarze, w którym ma działać instytut. Jednakże, pierwszy statut nowo utworzonemu instytutowi nadaje sam minister nadzorujący. Pierwszy statut obowiązuje do czasu zatwierdzenia przez ministra nadzorującego statutu uchwalonego przez radę naukową ${ }^{16}$.

Utworzenie instytutu jest poprzedzone postępowaniem przygotowawczym mającym na celu ocenę potrzeby oraz warunków jego utworzenia ${ }^{17}$. Postępowanie przygotowawcze ma na celu: 1) określenie dziedzin i zakresu badań naukowych lub prac rozwojowych oraz sektorów gospodarki i innych obszarów istotnych dla funkcjonowania państwa, w jakich powstała potrzeba utworzenia instytutu; 2) ocenę zasadności prowadzenia badań naukowych i prac rozwojowych w dziedzinach nauki oraz określonych sektorach gospodarki; 3) określenie możliwości spełnienia warunków wymaganych dla utworzenia instytutu w zakresie kadry, aparatury badawczej, laboratoriów, potencjału informatycznego oraz warunków materialno-technicznych ${ }^{18}$.

Minister właściwy ze względu na planowaną działalność instytutu powołuje zespół roboczy do przeprowadzenia postępowania przygotowawczego. W skład zespołu roboczego wchodzą trzy osoby wskazane przez ministra właściwego ze względu na planowaną działalność instytutu, w tym osoba posiadająca wiedzę i doświadczenie w obszarze zastosowania wyników prac badawczych oraz osoba posiadająca wiedzę i doświadczenie w zakresie zarządzania finansami oraz dwie osoby wskazane przez ministra właściwego do spraw nauki, reprezentujące dziedzinę nauki właściwą dla tworzonego instytutu ${ }^{19}$. Zespół roboczy przedstawia ministrowi opinię $\mathrm{w}$ sprawie utworzenia instytutu $\mathrm{w}$ terminie 2 miesię-

${ }^{15}$ Art. 5 ust. $1-2$ u.i.b.

16 Art. 6 ust. 2-3 u.i.b.

17 Art. 8 ust. 1 u.i.b.

$18 \S 2$ pkt 1-3 Rozporządzenia Rady Ministrów z dnia 17 listopada 2010 r. w sprawie tworzenia, łączenia, podziału, reorganizacji, przekształcania, włączania lub likwidacji instytutów badawczych, Dz. U. z 2010 r. Nr 230, poz. 1512.

19 § 3 Rozporządzenia Rady Ministrów z dnia 17 listopada 2010 r. 
cy od dnia jego powołania ${ }^{20}$. Ustawa nie przewiduje możliwości przedłużenia terminu przedstawienia ministrowi opinii przez zespół ${ }^{21}$. Opinia taka zawiera: 1) ocenę skutków finansowych utworzenia instytutu, w tym wpływu na sektor finansów publicznych; 2) ocenę wpływu na konkurencyjność gospodarki przedsiębiorstw oraz rynek pracy; 3) analizę konkurencji na rynku badań w dziedzinach nauki, w których miałby działać nowo utworzony instytut; 4) analizę sytuacji aktualnej i przyszłej na rynkach, na których mogłyby być wdrażane wyniki badań naukowych lub prac rozwojowych prowadzonych przez nowo utworzony instytut ${ }^{22}$.

Organem stanowiącym, inicjującym, opiniodawczym i doradczym instytutu w zakresie jego działalności statutowej oraz w sprawach rozwoju kadry naukowej i badawczo-technicznej jest jego rada naukowa ${ }^{23}$. Jak z samej nazwy wynika, organ ten cechuje kolegialność ${ }^{4}$. Rada naukowa działa na podstawie uchwalonego przez siebie regulaminu ${ }^{25}$. Jej uprawnienia stanowią katalog zamknięty ${ }^{26}$ i są enumeratywnie wymienione przez ustawę: 1) uchwalenie statutu instytutu; 2) opiniowanie kandydatów na stanowiska: zastępcy dyrektora do spraw naukowych, sekretarza naukowego oraz kierowników komórek organizacyjnych wskazanych w regulaminie organizacyjnym instytutu, odpowiedzialnych za prowadzenie badań naukowych; 3) opiniowanie kierunkowych planów tematycznych badań naukowych i prac rozwojowych oraz finansowych instytutu, a także rocznych sprawozdań dyrektora z wykonania zadań; 4) zatwierdzanie perspektywicznych kierunków działalności naukowej, rozwojowej i wdrożeniowej; 5) opiniowanie wniosków w sprawie połączenia, podziału, przekształcenia lub reorganizacji instytutu oraz stałej współpracy instytutu z innymi osobami prawnymi; 6) opiniowanie (regulaminu organizacyjnego, rocznego planu finansowego, rocznych sprawozdań finansowych, podziału zysku instytutu); 7) opiniowanie kwalifikacji osób na stanowiska pracowników naukowych i badawczo-technicznych oraz dokonywanie okresowej oceny dorobku naukowego i technicznego tych pracowników; 8) opiniowanie wniosków o przyznawanie stypendiów naukowych; 9) przeprowadzanie przewodów doktorskich i habilitacyjnych oraz postępowań o nadanie tytułu naukowego w zakresie posiadanych uprawnień; 10) wnioskowanie do dyrektora o mianowanie na stanowisko profesora

\footnotetext{
${ }^{20}$ Art. 8 ust. 2 u.i.b.

${ }^{21}$ Zob. D. Michta, Ustawa o instytutach badawczych, s. 45.

22 § 4 Rozporządzenia Rady Ministrów z dnia 17 listopada 2010 r.

23 Art. 29 ust. 1 u.i.b.

${ }^{24}$ Zob. D. Michta, Ustawa o instytutach badawczych, s. 85.

25 Art. 30 ust. 9 u.i.b.

${ }^{26}$ Zob. D. Michta, Ustawa o instytutach badawczych, s. 85.
} 
zwyczajnego lub profesora nadzwyczajnego; 11) opiniowanie programów prowadzonych przez instytut studiów podyplomowych i doktoranckich; 12) opiniowanie regulaminu zarządzania prawami autorskimi i prawami pokrewnymi oraz prawami własności przemysłowej oraz zasad komercjalizacji wyników badań naukowych i prac rozwojowych; 13) przypisywanie ram kwalifikacyjnych do kwalifikacji nadawanych po ukończeniu studiów podyplomowych oraz podejmowanie decyzji o włączeniu do Zintegrowanego Systemu Kwalifikacji - kwalifikacji nadawanych po ukończeniu takich studiów (zgodnie z ustawą z dnia 22 grudnia 2015 r. o Zintegrowanym Systemie Kwalifikacji ${ }^{27}$ ); 14) występowanie do ministra właściwego według działów administracji rządowej, z wnioskiem o włączenie do Zintegrowanego Systemu Kwalifikacji - kwalifikacji nadawanych po ukończeniu innych form kształcenia (szkoleń, kursów dokształcających) ${ }^{28}$.

Rada naukowa jest uprawniona do zajmowania stanowiska we wszystkich sprawach dotyczących działalności instytutu ${ }^{29}$, a opinie sporządza $\mathrm{w}$ terminie nie dłuższym niż $30 \mathrm{dni}^{30}$. W jej posiedzeniach biorą udział dyrektor, przedstawiciel zakładowych organizacji związkowych oraz inne osoby zaproszone przez przewodniczącego rady naukowej ${ }^{31}$.

Skład rady naukowej powinien odzwierciedlać ogół osób zatrudnionych $w$ instytucie ${ }^{32}$. W skład rady naukowej instytutu wchodzi nie mniej niż dwanaście i nie więcej niż czterdzieści osób. Statut instytutu określa liczbę tych osób oraz proporcje udziału osób posiadających stopień naukowy doktora oraz stopień naukowy doktora habilitowanego lub tytuł naukowy, wchodzących w skład rady naukowej i będących pracownikami instytutu ${ }^{33}$. W skład rady naukowej, w liczbie określonej w statucie instytutu, wchodzą: 1) pracownicy naukowi i badawczo-techniczni instytutu (stanowią oni co najmniej 40\% składu rady); 2) osoby niebędące pracownikami instytutu, które stanowią co najmniej 50\% składu rady ${ }^{34}$. Osoby posiadające stopień naukowy doktora habilitowanego lub tytuł naukowy, zatrudnione w pełnym wymiarze czasu pracy w instytucie (nie krócej niż rok od dnia rozpoczęcia procedury powołania rady naukowej), wchodzą w jej skład w liczbie określonej w statucie ${ }^{35}$. Do rady naukowej wchodzą także osoby spoza instytutu, posiadające co najmniej stopień naukowy doktora oraz osoby wyróż-

\footnotetext{
27 Dz. U. z 2016 r. poz. 64 z późn. zm.

28 Art. 29 ust. 2 u.i.b.

29 Art. 29 ust. 5 u.i.b.

30 Art. 29 ust. 6 u.i.b.

31 Art. 31 ust. 4 u.i.b.

32 Zob. D. Michta, Ustawa o instytutach badawczych, s. 86.

33 Art. 30 ust. 1 u.i.b.

34 Art. 30 ust. 2 u.i.b.

35 Art. 30 ust. 3 u.i.b.
} 
niające się wiedzą i praktycznym dorobkiem w sferze gospodarczej objętej działalnością instytutu. Osoby te powołuje do rady minister nadzorujący, w tym spośród kandydatów przedstawionych przez dyrektora instytutu ${ }^{36}$. Sam dyrektor, jego zastępcy oraz główny księgowy wchodzą do rady z urzędu, jeżeli posiadają stopień naukowy doktora habilitowanego lub tytuł naukowy i są zatrudnione w instytucie w pełnym wymiarze czasu pracy nie krócej niż rok od dnia rozpoczęcia procedury powołania rady. Mają oni prawo głosu w sprawach opiniowania kwalifikacji osób na stanowiska pracowników naukowych i badawczo-technicznych oraz prawo dokonywania okresowej oceny dorobku naukowego i technicznego tych pracowników. Ponadto, opiniują wnioski o przyznanie stypendiów naukowych oraz przeprowadzenia przewodów doktorskich i habilitacyjnych oraz postępowań o nadanie tytułu naukowego w zakresie posiadanych uprawnień ${ }^{37}$.

Przewodniczącego rady i jego zastępców, rada wybiera spośród swoich członków w głosowaniu tajnym. Zasada tajności oznacza, że głosowanie odbywa się w sposób anonimowy i nikt $z$ osób trzecich nie ma prawa ingerować w przebieg takiego głosowania. Głosowanie jest tajne wówczas, gdy znana jest tylko liczba głosów i wyniki, lecz nie jest możliwe ustalenie, kto i w jaki sposób głosował ${ }^{38}$. Przewodniczącego rady naukowej wybiera się spośród członków rady powołanych przez ministra nadzorującego. Przewodniczącym rady naukowej może być osoba posiadająca co najmniej stopień naukowy doktora. Natomiast funkcja zastępcy przewodniczącego rady naukowej nie może być łączona ze stanowiskiem dyrektora, zastępcy dyrektora lub głównego księgowego instytutu ${ }^{39}$.

Rada naukowa zbiera się na posiedzeniach plenarnych, natomiast pomiędzy posiedzeniami rady, w sposób ciągły działa jej prezydium ${ }^{40}$. Szczególna rola przy pada jednak przewodniczącemu rady, w którego kompetencjach spoczywa przekazanie ministrowi nadzorującemu (minister właściwy ze względu na obszar działalności instytutu) uchwał rady w następujących sprawach: 1) opiniowania kierunkowych planów tematycznych badań naukowych i prac rozwojowych oraz finansowych instytutu, a także rocznych sprawozdań dyrektora z wykonania zadań; 2) zatwierdzania perspektywicznych kierunków działalności naukowej, rozwojowej i wdrożeniowej rady; 3) opiniowania wniosków dotyczących połączenia, podziału, przekształcenia lub reorganizacji instytutu oraz stałej współpracy instytutu z innymi osobami prawnymi; 4) opiniowania regulaminu organiza-

\footnotetext{
36 Art. 30 ust. 4 u.i.b.

37 Art. 30 ust. 5 u.i.b.

38 Zob. D. Michta, Ustawa o instytutach badawczych, s. 86.

39 Art. 31 ust. 1-3 u.i.b.

40 Zob. D. Michta, Ustawa o instytutach badawczych, s. 87.
} 
cyjnego, rocznego planu finansowego, rocznych sprawozdań finansowych, podziału zysku instytutu; 5) opiniowania regulaminu zarządzania prawami autorskimi i prawami pokrewnymi oraz prawami własności przemysłowej oraz zasad komercjalizacji wyników badań naukowych i prac rozwojowych; 6) przypisywania poziomów Polskiej Ramy Kwalifikacji do kwalifikacji nadawanych po ukończeniu studiów podyplomowych oraz podejmowanie decyzji o włączeniu do Zintegrowanego Systemu Kwalifikacji kwalifikacji nadawanych po ukończeniu takich studiów (zgodnie z ustawą z dnia 22 grudnia 2015 r. o Zintegrowanym Systemie Kwalifikacji).

Termin na przekazanie uchwał ministrowi nadzorującemu instytut, w sprawach enumeratywnie wymienionych wynosi 7 dni od dnia ich podjęcia ${ }^{41}$. Ponieważ przepisy milczą na temat tego, czy i jakie ewentualne skutki może wywoływać niewykonanie lub nienależyte (spóźnione) wykonanie obowiązku przekazania uchwały, przyjmuje się, że termin ten ma charakter instrukcyjny (porządkowy), a jego przekroczenie nie pociąga za sobą żadnych negatywnych skutków, zarówno względem samej uchwały rady naukowej, jak i uprawnień organu nadzorczego ${ }^{42}$. Innymi słowy, przepisy nie przewidują odpowiedzialności przewodniczącego rady za niezachowanie terminu przekazania uchwały ministrowi nadzorującemu, co więcej, nie ma nawet podstaw prawnych do wyegzekwowania odpowiedzialności przewodniczącego, w sytuacji, gdyby w ogóle zaniechał obowiązku przekazania uchwały. Co prawda, w drodze wykładni funkcjonalnej można w tym wypadku posiłkować się przepisem art. 31 ust. 1 u.i.b., który choć stanowi jedynie o powołaniu przewodniczącego rady naukowej, to może także w szczególnych okolicznościach stanowić podstawę do jego odwołania. Za podstawę taką można by bezspornie uznać, np. całkowite zlekceważenie przez przewodniczącego obowiązku przekazania uchwały organowi nadzoru.

\section{Forma ingerencji nadzorczej i jej weryfikacja}

Termin „nadzór” uznawany jest za szczególnego rodzaju kompetencję służącą zapobieganiu lub usuwaniu naruszenia prawa przez podmiot uprawniony do określonego działania. $W$ owej kompetencji mieści się zarówno możność, jak i powinność władczego wkraczania, celem doprowadzenia (nadzór weryfikacyjny) albo utrzymania (nadzór prewencyjny) stanu

${ }^{41}$ Art. 35a ust. 1 u.i.b.

${ }^{42}$ Zob. wyrok Naczelnego Sądu Administracyjnego z dnia 22 listopada 1990 r., SA/Gd 965/90, ONSA 1990, Nr 4, poz. 11. 
zgodnego z prawem ${ }^{43}$. Poza kryterium legalności, uzupełniającymi kryteriami tej instytucji bywają w określonych prawem sytuacjach: rzetelność, celowość i gospodarność. Jednakże kryterium legalności jest zawsze wiodące.

Nadzór cechuje władczość, której atrybutem jest jednostronne kształtowanie sytuacji prawnej podmiotu nadzorowego, a także pozycji prawnej jego organów. Dlatego nadzór ujmuje się w kategoriach dynamicznego funkcjonowania administracji, przy czym pojęcie nadzoru odnosi się do różnych typów zależności organizacyjnych i funkcjonalnych oraz rozpatruje się to pojęcie na tle zróżnicowanych uregulowań prawnych. Stąd też, znaczenie terminu nadzór należy definiować każdorazowo, biorąc pod uwagę konkretny układ stosunków przewidzianych przez prawo ${ }^{44}$. Z ustawy też musi wynikać, jaki organ, w jakim zakresie i za pomocą jakich środków nadzorczych winien realizować nadzór ${ }^{45}$. O intensywności nadzoru, rozumianej jako węższy lub szerszy zakres ingerencji nadzorczej, decyduje ustawodawca, aczkolwiek podmiot nadzorowany nigdy nie jest pozbawiony ochrony prawnej przed nadzorem nieuprawnionym bądź przekraczającym granicę ingerencji nadzorczej. Przejawem tej ochrony jest sądowa kontrola administracji. W takich kategoriach należy rozpatrywać nadzór nad działalnością uchwałodawczą rad naukowych instytutów badawczych, o czym traktuje niniejsze opracowanie.

Minister nadzorujący może uchylić w całości lub w części uchwałę rady naukowej instytutu badawczego, podjętą w sprawach wyszczególnionych ustawowo, w przypadku stwierdzenia niezgodności takiej uchwały z przepisami prawa lub statutem instytutu. Uchylenie uchwały powinno nastąpić $w$ terminie 30 dni od dnia otrzymania uchwały ${ }^{46}$. Przepisy jednak nie wskazują, czy i ewentualnie jakie skutki prawne, może wywołać okoliczność nie zachowania tego terminu przez ministra. Brak takiej regulacji nie może jednak zaprzeczać charakterowi owego terminu, iż jest on prekluzyjny, a jego upływ powoduje, że minister traci uprawnienia nadzorcze względem nadzorowanej uchwały. Termin ten zatem bezwzględnie wiąże ministra, a do jego obliczenia stosuje się przepis art. $57 \S 1$ (ostatnie zdanie) Kodeksu postępowania administracyjnego ${ }^{47}$. Stanowi on, że upływ ostatniego z wyznaczonej liczby dni uważa się za koniec terminu. Jeżeli więc

${ }^{43}$ Zob. W. Miemiec [w:] M. Stec (red.), Regionalne izby obrachunkowe. Charakterystyka ustrojowa i komentarz do ustawy, Warszawa 2010, s. 309.

${ }_{44}$ Zob. W. Chróścielewski, Z. Kmieciak, Postępowanie w sprawach nadzoru nad działalnościa komunalna, Warszawa 1995, s. 11.

45 Zob. Z. Rybicki [w:] Z. Rybicki, S. Piątek, Zarys prawa administracyjnego i nauki administracji, Warszawa 1988, s. 257-258.

${ }_{46}$ Art. 35a ust. 2 u.i.b.

47 Ustawa z dnia 14 czerwca 1960 r. - Kodeks postępowania administracyjnego, Dz. U. z 2017 r. poz. 1257, tekst jednolity (dalej k.p.a.). 
ministrowi termin ten wypadnie na dzień ustawowo wolny od pracy lub na sobotę, termin na wydanie decyzji w sprawie uchylenia uchwały rady naukowej instytutu badawczego będzie upływał następnego dnia, który nie jest dniem wolnym od pracy ani sobotą ${ }^{48}$.

Formą uchylenia uchwały jest decyzja administracyjna (art. 35a ust. 2 u.i.b.). Może być ona podjęta w dwojakiej formie ${ }^{49}$ - tradycyjnej, czyli pisemnej, albo $\mathrm{w}$ formie dokumentu elektronicznego $\mathrm{w}$ rozumieniu przepisów ustawy z dnia 17 lutego 2005 r. o informatyzacji działalności podmiotów realizujących zadania publiczne ${ }^{50}$. Forma pisemna i forma dokumentu elektronicznego są alternatywnymi i równorzędnymi formami, w jakich mogą być wydawane decyzje administracyjne, aczkolwiek to do organu wydającego decyzję należy wybór jednej spośród tych form. W doktrynie prawa przyjmuje się, że wybór taki może zostać ograniczony przez przepis szczególny, który będzie wyraźnie wskazywał w jakiej formie decyzja administracyjna musi być wydana ${ }^{51}$.

Nadanie przez ustawodawcę aktowi nadzoru nad uchwałami rad naukowych instytutów badawczych formy decyzji administracyjnej powoduje tzw. uprocesowienie ingerencji nadzorczej, a co za tym idzie, poddanie tej procedury reżimowi Kodeksu postępowania administracyjnego ${ }^{52}$. Zgodnie zatem z przepisem art. 107 k.p.a., struktura decyzji w sprawie uchylenia uchwały rady naukowej instytutu badawczego, powinna zawierać: 1) oznaczenie organu wydającego decyzję - zatem wskazanie właściwego ministra nadzorującego konkretny instytut badawczy (z oznaczeniem nazwy pod którą funkcjonuje ten organ); 2) datę wydania decyzji, za którą przyjmuje się dzień jej podpisania przez ministra bądź osobę przez niego upoważnioną; 3) oznaczenie strony - nazwy instytutu badawczego (jako osoby prawnej) nie zaś nazwy jego organu (rady naukowej), pomimo, że to akt tego organu podlega nadzorowi; 4) wskazanie podstawy prawnej decyzji, którą bezpośrednio stanowi art. 35a ustawy o instytutach badawczych; 5) osnowę (sentencję) decyzji - przez co należy rozumieć zwrot stosunkowy, z treści którego wynika zakres uchylenia uchwały rady naukowej instytutu (uchylenie w całości lub w części, z ewentualnym wskazaniem konkretnych przepisów uchwały, które podlegają derogacji); 6) uzasadnienie prawne i faktyczne, świadczące o motywach rozstrzygnięcia przyjętego

${ }^{48}$ Art. $57 \S 4$ k.p.a.

49 Art. $14 \S 1$ k.p.a.

${ }^{50}$ Ustawa z dnia 17 lutego 2005 r. o informatyzacji działalności podmiotów realizujących zadania publiczne, Dz. U. z 2017 r. poz. 570, tekst jednolity.

${ }^{51}$ Zob. H. Knysiak-Molczyk [w:] H. Knysiak-Molczyk (red.), Kodeks postępowania administracyjnego. Komentarz, Warszawa 2015, s. 104.

52 Dz. U. z 2017 r. poz. 1257; z 2018 r. poz. 149, 650, tekst jednolity. 
w sentencji. Motywem uchylenia uchwały rady naukowej będzie zawsze naruszenie prawa albo statutu instytutu, jednakże właściwe uzasadnienie motywacji winno w takim wypadku obejmować precyzyjne określenie zakresu naruszenia, a nawet jego stopnia. Stopień naruszenia prawa może być różny, w zależności od rodzaju sprzeczności pomiędzy przepisem kontrolowanym a przepisem będącym punktem odniesienia. Można tu rozgraniczyć trzy sytuacje. Po pierwsze, kiedy naruszenie prawa jest istotne, po drugie, kiedy takiej cechy nie wykazuje (można by nawet odstąpić od uchylenia uchwały w takiej sytuacji), wreszcie po trzecie, gdy naruszenie prawa jest rażące, tzn. o najcięższym „wymiarze gatunkowym”. Warto w miejscu tym zaznaczyć, że każde rażące naruszenia prawa jest istotnym, ale też nie każde istotne jest rażącym.

Decyzja w sprawie uchylenia uchwały rady naukowej instytutu badawczego musi w swej treści zawierać także dwa nie wymienione wyżej elementy, do których należą podpis piastuna organu (osoby pełniącej w danym momencie funkcję ministra) albo osoby przez nią upoważnionej w ramach dekoncentracji wewnętrznej (art. 268a k.p.a. ${ }^{53}$ ) oraz pouczenie o przysługującym od decyzji środku zaskarżenia.

Podpis pod decyzją świadczy o jej wydaniu w znaczeniu formalnym. Co prawda, nie powoduje to jeszcze włączenia decyzji do obrotu prawnego, jednakże podpis identyfikuje tego, kto decyzję wydał ${ }^{54}$. Ponieważ decyzję w sprawie uchylenia uchwały rady naukowej instytutu badawczego podejmuje odpowiedni minister nadzorujący, zatem organ, nad którym nie istnieje inny organ wyższego stopnia (biorąc pod uwagę administracyjny tok instancji), w pouczeniu o środku zaskarżenia powinien być zacytowany przepis art. $127 \S 3$ k.p.a., który stanowi, m.in. o tym, że od decyzji wydanej przez ministra nie służy odwołanie, jednakże strona niezadowolona z decyzji może zwrócić się do tego organu z wnioskiem o ponowne rozpatrzenie sprawy. Do wniosku takiego stosuje się odpowiednio przepisy dotyczące odwołań od decyzji.

Związanie decyzją administracyjną następuje z chwilą jej doręczenia, niezależnie od formy: czy to tradycyjnej (pisemnej), czy elektronicznej. Cechą związania jest to, że przed terminem złożenia wniosku o ponowne rozpatrzenie sprawy (jak $\mathrm{w}$ analizowanym przypadku na podstawie art. 127 § 3 k.p.a. - gdy decyzję wydaje minister), brak jest możliwości zmia-

${ }^{53}$ Przepis ten stanowi, że „Organ administracji publicznej może upoważniać, w formie pisemnej, pracowników obsługujących ten organ do załatwiania spraw w jego imieniu w ustalonym zakresie, a w szczególności do wydawania decyzji administracyjnych, postanowień i zaświadczeń".

54 Art. 268a k.p.a. 
ny decyzji przez organ z własnej inicjatywy ${ }^{55}$. Zmiana albo też uchylenie decyzji jest dopiero możliwe $\mathrm{w}$ wyniku ponownego rozpatrzenia sprawy.

W przypadku decyzji dotyczącej uchylenia uchwały rady naukowej instytutu badawczego, wniosek o ponowne rozpatrzenie sprawy wnosi dyrektor instytutu bądź osoba przez niego upoważniona - działa ona jednak w jego imieniu. Nie należy bowiem tracić z pola widzenia faktu, że to dyrektor instytutu reprezentuje go na zewnątrz i działa z jego ramienia ${ }^{56}$.

Wniosek o ponowne rozpatrzenie sprawy, podobnie jak odwołanie $\mathrm{w}$ administracyjnym toku instancji, nie wymaga uzasadnienia. Wystarczy, że instytut będzie wyrażał swoje niezadowolenie z samej decyzji uchylającej uchwałę rady naukowej ${ }^{57}$. Owo odformalizowanie uznaje się jako daleko idący przejaw ochrony tego, kto z takiego środka prawnego korzysta $^{58}$. Oczywiście nic nie stoi na przeszkodzie, aby instytut we wniosku o ponowne rozpatrzenie sprawy uchylenia uchwały jego rady naukowej, sformułował zarzuty wobec skarżonej decyzji, o ile z jednej strony będzie wyrażał przekonanie, że podjęta uchwała jest zgodna z prawem lub statutem instytutu, a decyzja uchylająca tę uchwałę jest sprzeczna z prawem. Wykazanie sprzeczności decyzji objętej wnioskiem o ponowne rozpatrzenie sprawy musi jednak ściśle korespondować z wykazaniem, że podjęta uchwała nie naruszała prawa bądź statutu.

Spóźniony wniosek o ponowne rozpatrzenie sprawy, o ile nie nastąpiło przywrócenie terminu do jego wniesienia (art. $58 \S 1$ k.p.a. ${ }^{59}$ ), czyni decyzję nadzorczą ostateczną, a jej podważenie jest natomiast możliwe (zgodnie z zasadą trwałości decyzji administracyjnej wyrażoną w art. $16 \S 1$ k.p.a.), jedynie w nadzwyczajnym trybie postępowania administracyjnego, $\mathrm{z}$ egzemplifikacją kwalifikowanych wad decyzji, skutkujących stwierdzeniem jej nieważności (wg art. 156 § 1 k.p.a.). Sankcja taka może być podyktowana następującymi okolicznościami: 1) wydaniem decyzji z naruszeniem przepisów o właściwości (przykładowo: uchwałę rady naukowej wojskowego instytutu badawczego uchyla Minister Zdrowia, a nie Minister Obrony Narodowej); 2) wydaniem decyzji z rażącym naruszeniem prawa (np. minister nadzorujący uchyla uchwałę spoza katalogu spraw wymienionego w art. 35a u.i.b.); 3) wydaniem decyzji uchylającej uchwałę, uchyloną już wcześniej inną decyzją ostateczną. W tym wypadku chodzi więc o zacho-

${ }_{55}$ Zob. J. Borkowski [w:] B. Adamiak, J. Borkowski, Kodeks postępowania administracyjnego. Komentarz, Warszawa 2016, s. 531.

56 Art. 24 ust. 1 pkt 5 u.i.b.

${ }^{57}$ Art. 128 k.p.a.

58 Zob. Z. Kmieciak, Odwołanie w postępowaniu administracyjnym, Warszawa 2011, s. 71.

${ }^{59}$ Przepis ten stanowi, że „w razie uchybienia terminu należy przywrócić termin na prośbę zainteresowanego, jeżeli uprawdopodobni, że uchybienie nastąpiło bez jego winy". 
wanie formuły zakazu ponownego orzekania w tożsamościowo tej samej sprawie (ne bis in idem), a tym samym przestrzeganie zasady res iudicata ${ }^{60}$.

Ponowne rozpatrzenie sprawy dotyczącej uchylenia uchwały rady naukowej instytutu badawczego jest przejawem (wprawdzie bez dewolucji kompetencji) realizacji zasady dwuinstancyjności postępowania (art. 15 k.p.a.), której istota sprowadza się do ponownego merytorycznego rozpatrzenia tej samej sprawy (zatem $\mathrm{w}$ analizowanym przypadku - zasadności uchylenia uchwały rady naukowej instytutu badawczego) ${ }^{61}$. Jest to swoista gwarancja tzw. sprawiedliwości proceduralnej, która ma eliminować albo co najmniej minimalizować ryzyko związane z arbitralnością oraz pomyłkami przy pierwszym (pierwszoinstancyjnym) rozstrzygnięciu sprawy ${ }^{62} . Z$ racji tego, że ponowne rozpatrzenie sprawy odbywa się przed tym samym organem, który wydał pierwotną decyzję (ministrem nadzorującym), organ ten sam może usunąć ewentualnie popełnione przez siebie błędy, biorąc pod uwagę zarówno kontekst formalny jak i materialny wydanej decyzji. Wynik ponownego rozpatrzenia sprawy odpowiada rezultatom postępowania odwoławczego, co zostało expressis verbis wyrażone w ostatnim zdaniu przepisu art. $127 \S 3$ k.p.a., który nakazuje odpowiednie stosowanie przepisów dotyczących odwołań. Stąd, minister nadzorujący uchwałę rady naukowej instytutu badawczego jest zobowiązany do przestrzegania reguł orzekania wyrażonych w art. 138 § 1 k.p.a. Należą do nich alternatywnie: 1) utrzymanie w mocy zaskarżonej decyzji (gdy decyzja jest zgodna z prawem); 2) uchylenie zaskarżonej decyzji w całości albo w części i orzeczenie w tym zakresie co do istoty sprawy (np. w sytuacji, gdy uległa zmianie kwalifikacja naruszenia prawa bądź statutu przez uchwałę rady instytutu); 3) uchylenie decyzji i umorzenie postępowania nadzorczego (gdy nie było podstaw do ingerencji nadzorczej, np. nadzorem objęto projekt uchwały przed jej podjęciem).

Związanie ministra nadzorującego uchwałę rady naukowej instytutu badawczego przepisami dotyczącymi odwołań (przy ponownym rozpatrzeniu sprawy) oznacza jeszcze jedną daleko idącą konsekwencję. Mianowicie (tak jak w postępowaniu odwoławczym) obowiązek przestrzegania zasady zakazu reformationis in peius ${ }^{63}$. Oznacza ona, że organ odwoławczy albo organ, który ponownie rozpatruje sprawę, nie może pogorszyć sytuacji strony w stosunku do sytuacji powstałej w wyniku pierwotnego rozpatrzenia sprawy. Należy przyjąć, że chodzi w tym wypadku o takie sytuacje

${ }^{60}$ Zob. J. Borkowski [w:] B. Adamiak, J. Borkowski, Kodeks postępowania..., s. 766.

${ }^{61}$ Zob. wyrok Wojewódzkiego Sądu Administracyjnego w Krakowie z dnia 6 marca 2012 r., II SA/Kr 1889/11, LEX nr 1138574.

${ }^{62}$ H. Knysiak-Molczyk, Kodeks postępowania..., s. 106.

63 Art. 139 k.p.a. 
jak: albo nałożenie większego obowiązku, aniżeli wynikającego z zaskarżonej odwołaniem decyzji, albo ograniczenie (zmniejszenie) uprawnienia przyznanego taką decyzją ${ }^{64}$. Odnosząc to do postępowania nadzorczego nad uchwałami rad naukowych instytutów badawczych, przestrzeganie zasady zakazu reformationis in peius będzie oznaczało np. niemożność uchylenia w całości uchwały rady naukowej po ponownym rozpatrzeniu sprawy, jeżeli w trybie art. 35a ust. 2 u.i.b. minister uchylił uchwałę tylko w części. Wyjątek może stanowić przewidziane w art. 139 k.p.a. odejście od zakazu orzekania na niekorzyść strony, ale tylko wtedy, gdy pierwsza decyzja (w analizowanym przypadku wydana na podstawie art. 35a ust. 2 u.i.b.), rażąco naruszałaby prawo. Przykładowo, decyzja nadzorcza może rażąco naruszać prawo, jeśli w wyniku jej wydania doszło jedynie do częściowego uchylenia uchwały rady naukowej, podczas, gdy z powodu sprzeczności z prawem albo statutem, uchwała taka winna zostać uchylona w całości. Siłą rzeczy, po ponownym rozpatrzeniu sprawy (wbrew zakazowi reformationis in peius, lecz zgodnie z art. 139 k.p.a.), dojdzie do pogorszenia sytuacji strony (instytutu), ale będzie to uzasadnione okolicznościami wskazanymi w tym przepisie.

\section{Skarga sądowoadministracyjna na decyzję nadzorczą i prawo samokontroli}

Instytut badawczy może bronić się przed niekorzystnym dla siebie rozstrzygnięciem nadzorczym (również wówczas, gdy po ponownym rozpatrzeniu sprawy utrzymano w mocy decyzję uchylającą uchwałę) w trybie sądowej weryfikacji decyzji. Co więcej, zgodnie z art. $52 \S 3$ ustawy - Prawo o postępowaniu przed sądami administracyjnymi ${ }^{65}$, $\mathrm{w}$ brzmieniu nadanym przez art. 9 pkt 2 lit. a ustawy z dnia 7 kwietnia 2017 r. o zmianie ustawy Kodeks postępowania administracyjnego oraz niektórych innych ustaw ${ }^{66}$ (z datą wejścia w życie z dniem 1 czerwca 2017 r.), jeżeli stronie przysługuje prawo do zwrócenia się do organu, który wydał decyzję z wnioskiem o ponowne rozpatrzenie sprawy, strona może wnieść skargę na tę decyzję bez skorzystania z tego prawa. Oznacza to, że instytut broniąc uchwały wydanej przez jego radę naukową, może sięgnać dwutorowo po środ-

${ }^{64}$ Zob. A. Golęba [w:] H. Knysiak-Molczyk (red.), Kodeks postępowania..., s. 949.

${ }^{65}$ Ustawa z dnia 30 sierpnia 2002 r. - Prawo o postępowaniu przed sądami administracyjnymi, Dz. U. z 2018 r. poz. 1302.

${ }_{66}$ Ustawa z dnia 7 kwietnia 2017 r. o zmianie ustawy - Kodeks postępowania administracyjnego oraz niektórych innych ustaw, Dz. U. z 2017 r. poz. 935. 
ki prawne. Po pierwsze, może skorzystać najpierw z omówionego wyżej prawa do ponownego rozpatrzenia sprawy i dopiero później (po takim rozpatrzeniu wnieść skargę sądowoadministracyjną), albo bezpośrednio skierować taką skargę bez korzystania z tego prawa. Zatem zaskarżyć do sądu bezpośrednio decyzję wydaną na podstawie art. 35a ust. 2 u.i.b. Jakkolwiek wybór drogi skarżenia decyzji nadzorczej (pierwotnej czy po ponownym rozpatrzeniu sprawy) do sądu administracyjnego jest $\mathrm{w}$ istocie skróceniem lub wydłużeniem weryfikacji aktu nadzoru - zawsze stanowi realizację publicznego prawa podmiotowego ${ }^{67}$. Legitymacja do złożenia skargi przysługuje samemu instytutowi - jako osobie prawnej, jednakże imieniem instytutu uprawnionym do jej wniesienia będzie organ go reprezentujący - dyrektor (jak w przypadku wniosku o ponowne rozpatrzenie sprawy w trybie art. $127 \S 3$ k.p.a.).

Zgodnie $z$ art. 54 § 3 ustawy - Prawo o postępowaniu przed sądami administracyjnymi, w brzmieniu nadanym przez art. 9 pkt 4 ustawy o zmianie ustawy - Kodeks postępowania administracyjnego oraz niektórych innych ustaw, organ, którego działanie zaskarżono, może w zakresie swojej właściwości uwzględnić skargę w całości w terminie trzydziestu dni od dnia jej otrzymania. W przypadku skargi na decyzję, uwzględniając skargę w całości, organ uchyla zaskarżoną decyzję i wydaje nową. Uwzględniając skargę, organ stwierdza jednocześnie, czy działanie miało miejsce bez podstawy prawnej albo z rażącym naruszeniem prawa. Prawo do samokontroli decyzji jest rezultatem przyjętego unormowania, że skargę do sądu administracyjnego wnosi się za pośrednictwem organu, którego działanie (np. wydanie decyzji) jest przedmiotem skargi ${ }^{68}$. W doktrynie prawa podkreśla się, że uprawnienie samokontrolne ma tę zaletę, że nie angażuje sądu administracyjnego (zatem odciąża sąd) w rozstrzygnięciu sprawy będącej przedmiotem skargi ${ }^{69}$.

Minister nadzorujący uchwałę rady naukowej instytutu badawczego, korzystając z uprawnienia samokontrolnego (niezależnie, czy będzie chodziło o pierwszą decyzję nadzorczą, czy też o wydaną po ponownym rozpatrzeniu sprawy), winien uwzględnić w całości skargę instytutu, co praktycznie powinno przełożyć się na uznanie, że uchylenie w całości lub w części uchwały rady naukowej było w pełni bezpodstawne. Innymi słowy, nie było przesłanek do takiego uchylenia, albowiem poddana nadzorowi uchwała nie naruszała prawa ani statutu instytutu. W dalszej ko-

${ }^{67}$ Zob. B. Adamiak, J. Borkowski, Instytucje prawne sądowej ochrony samodzielności gminy, "Samorząd Terytorialny” 1991, nr 1/2, s. 40.

${ }_{68}$ Art. 54 § 1 Prawo o postępowaniu przed sądami administracyjnymi. s. 210 .

${ }^{69}$ Zob. T. Woś [w:] T. Woś (red.), Postępowanie sądowoadministracyjne, Warszawa 2015, 
lejności (w ramach uprawnienia samokontrolnego), mieści się uchylenie zaskarżonej decyzji i w jej miejsce wydanie nowej. Tu jednak zarysowuje się pewien problem, gdyż nawet jeśli minister nadzorujący uchwałę rady naukowej instytutu stwierdzi, że nie było podstaw do ingerencji nadzorczej (uchylenia uchwały), to nie może przykładowo wydać decyzji, która stwierdzałaby, że uchwała tej rady jest zgodna z prawem. Żaden przepis ustawy o instytutach badawczych, nie przewiduje bowiem wydania decyzji o pozytywnej weryfikacji uchwały rady instytutu. Co najwyżej, uwzględniając skargę, minister może „złagodzić” środek nadzoru, w postaci jedynie uchylenia w części uchwały rady naukowej, jeśli pierwotnie uchylił ją w całości. W tym wypadku, oczywiście trzeba wykazać, że tylko niektóre przepisy (pozostające w mniejszości) są niezgodne z prawem lub statutem instytutu.

Wspomniana wcześniej nowelizacja ustawy - Kodeks postępowania administracyjnego oraz niektórych innych ustaw, w tym ustawy - Prawo o postępowaniu przed sądami administracyjnymi, radykalnie zmieniła uprawnienia samokontrolne organu administracji, po wniesieniu skargi. Zgodnie bowiem z art. $54 \S 3$ ostatniej z wymienionych ustaw, organ, który korzysta z uprawnienia samokontrolnego, musi oprócz uwzględniania skargi także odnieść się do tego, czy wydana przez niego decyzja nosiła znamiona rażącego naruszenia prawa albo została wydana bez podstawy prawnej. Rażące naruszenie prawa jest pojęciem niedookreślonym, o nieostrym znaczeniu, którego podstawową cechą jest jego oczywistość oraz bezsporność. Takie naruszenie nie wywołuje kontrowersji interpretacyjnych, co do jego bezpośredniego rozumienia, albowiem dla jego stwierdzenia wystarczy proste zestawienie ze sobą przepisu naruszonego z naruszającym ${ }^{70}$. Przekładając to na przedmiot analizowanego zagadnienia, trzeba byłoby wykazać swego rodzaju odwrotność sytuacji, mianowicie, że treść decyzji uchylającej uchwałę pozostaje w pełnej sprzeczności z treścią uchylanej uchwały, która w żadnym miejscu nie narusza prawa ani statutu instytutu.

Łatwiejsze do zdiagnozowania jest oczywiście wykazanie braku podstawy prawnej decyzji - zatem braku przepisu prawnego uprawniającego do wydania decyzji. Na gruncie ustawy o instytutach badawczych, można bezspornie stwierdzić, że minister nadzorujący uchwały rady naukowej instytutu badawczego, nie ma podstaw prawnych do wydania decyzji (ingerencji nadzorczej) w sprawach następujących uchwał: 1) statutowej instytutu; 2) dotyczących opiniowania kandydatów na stanowiska: zastępcy dyrektora do spraw naukowych, sekretarza naukowego oraz kierowników komórek organizacyjnych wskazanych w regulaminie organizacyjnym, od-

${ }^{70}$ Zob. wyrok Wojewódzkiego Sądu Administracyjnego w Warszawie z dnia 30 marca 2004 r., IV SA/Wa 3763/02, LEX nr 156952. 
powiedzialnych za prowadzenie badań naukowych; 3) w sprawach wyrażenia opinii odnośnie kwalifikacji osób na stanowiska pracowników naukowych i badawczo-technicznych oraz uchwał dokonujących okresowej oceny dorobku naukowego i technicznego tych pracowników; 4) uchwał dotyczących opinii w sprawie wniosków o przyznawanie stypendiów naukowych; 5) w sprawie przeprowadzania przewodów doktorskich i habilitacyjnych oraz postępowań o nadanie tytułu naukowego $\mathrm{w}$ zakresie posiadanych uprawnień; 6) w sprawie wniosku do dyrektora o mianowanie na stanowisko profesora zwyczajnego lub profesora nadzwyczajnego; 7) w sprawie opiniowania programów prowadzonych przez instytut studiów podyplomowych i doktoranckich; 8) w sprawie wystąpienia do ministra właściwego (według działów administracji rządowej), z wnioskiem o włączenie do Zintegrowanego Systemu Kwalifikacji - kwalifikacji nadawanych po ukończeniu innych form kształcenia, w tym szkoleń i kursów dokształcających ${ }^{71}$.

\section{Konkluzje}

Niniejsze opracowanie swoimi korzeniami sięga przede wszystkim do nowej regulacji prawnej - art. 35a ustawy o instytutach badawczych, wprowadzonej przez art. 1 pkt 11 ustawy z dnia 22 czerwca 2016 r. o zmianie ustawy o instytutach badawczych ${ }^{72}$, a następnie znowelizowanej przez art. 1 pkt 12 lit. a i b ustawy z dnia 16 grudnia 2016 r. o zmianie ustawy o instytutach badawczych oraz ustawy - Prawo geologiczne i górnicze ${ }^{73}$.

Kluczową kwestią, wokół której skupiono tok wyżej przedstawionych rozważań - stanowiących także zasadniczy punkt odniesienia wobec stawianych przez autora tez, była forma prawna w jakiej wyraża się nadzór nad uchwałami rad naukowych instytutów badawczych, a formą tą jest decyzja administracyjna. Jest ona jedną z podstawowych form działania administracji, wykazującą cechy władztwa, przeniesioną także na grunt postępowań niezaliczanych jednoznacznie do postępowań administracyjnych - postępowań nadzorczych w administracji.

Przyjmując, że formą władczego administrowania jest decyzja administracyjna, to nadzór wykonywany za pomocą takiego aktu, stanowi o administrowaniu poprzez nadzór. Jedynym kryterium takiej formy administrowania jest legalność - zatem, na podstawie art. 35a ustawy o instytutach

\footnotetext{
${ }^{71}$ Art. 35a ust. 1 u.i.b.

72 Dz. U. z 2016 r. poz. 1079.

${ }^{73}$ Dz. U. z 2017 r. poz. 202.
} 
badawczych, zgodność uchwały rady instytutu badawczego z powszechnie obowiązującym prawem oraz jego statutem.

Wybór przez ustawodawcę takiej formy aktu nadzoru nad uchwałami rad naukowych instytutów badawczych nie pozostawia wątpliwości, że w kwestiach nie unormowanych w ustawie o instytutach badawczych, należy posiłkowo stosować przepisy Kodeksu postępowania administracyjnego, dotyczące wydawania decyzji administracyjnych. Pomimo braku wprost takiego odesłania (art. 35a u.i.b. pomija tę kwestię), faktem jest, że nie mamy tu do czynienia z jakąkolwiek formą dekodyfikacji (wyłączenia spod zastosowania przepisów k.p.a.). Przeciwnie, obowiązek stosowania przepisów k.p.a. w postępowaniu nadzorczym nad uchwałami rad naukowych instytutów badawczych, znajduje swoje mocne uzasadnienie $\mathrm{w}$ znanych prawu proceduralnemu gwarancjach procesowych $\mathrm{w}$ administracji (związanie wydaną decyzją, prawo do złożenia wniosku o ponowne rozpatrzenie sprawy).

Konkluzja niniejszego opracowania sprowadza się w zasadzie do jednoznacznego wniosku, będącego $\mathrm{w}$ istocie postulatem de lege ferenda, że nowelizacja art. 35a ustawy o instytutach badawczych (jeśli ustawodawca zdecyduje się na taki krok), winna iść w kierunku expressis verbis odesłania do odpowiedniego stosowania przepisów k.p.a., przy wydawaniu decyzji w sprawie uchylenia uchwały rady naukowej instytutu badawczego. Co więcej, owo odesłanie powinno być tak zredagowane, aby obejmowało swym zasięgiem nie tylko samo wydanie decyzji, ale także czynności poprzedzające, jak i czynności następujące po wydaniu decyzji nadzorczej.

W ramach wniosku de lege ferenda, warto byłoby też normatywnie scharakteryzować istotę terminu $7 \mathrm{dni}$, w którym przewodniczący rady naukowej instytutu badawczego jest zobowiązany przedłożyć uchwałę nadzorującemu ministrowi. Dzisiaj mamy w zasadzie do czynienia tylko z terminem o charakterze instrukcyjnym, zatem którego niezachowanie, nie pociąga za sobą żadnych skutków prawnych. Zdecydowanie większym zaniechaniem prawodawczym jest jednak brak ustawowej regulacji, na wypadek, gdyby przewodniczący rady naukowej instytutu badawczego w ogóle nie wywiązał się z obowiązku przekazania do nadzoru uchwały rady naukowej instytutu. Wydaje się to nie do pogodzenia z zasadami demokratycznego państwa prawa.

Końcowo wypada jeszcze zaakcentować, że dla spójności regulacji prawnej zawartej w art. 35a ustawy o instytutach badawczych, warto byłoby znaleźć miejsce dla unormowania wprost odnoszącego się do prawa skargi sądowo-administracyjnej na decyzję nadzorczą w sprawie uchylenia uchwały rady naukowej instytutu badawczego. Ratio legis takiej regulacji należy wprost wywodzić z treści art. 3 § 2 pkt 1 ustawy - Prawo o postępowaniu 
przed sądami administracyjnymi, którego systematyka nadaje szczególną rolę kognicji sądów administracyjnych nad decyzjami administracyjnymi.

Słowa kluczowe: instytut badawczy, nadzór, decyzja administracyjna

\section{Bibliografia}

Adamiak B., J. Borkowski, Instytucje prawne sadowej ochrony samodzielności gminy, "Samorząd Terytorialny" 1991, nr 1/2, s. 38-45.

Adamiak B., J. Borkowski, Kodeks postępowania administracyjnego. Komentarz, Warszawa 2016.

Chróścielewski W., Z. Kmieciak, Postępowanie w sprawach nadzoru nad działalnościa komunalna, Warszawa 1995.

Cilak M., Instytuty badawcze jako forma działalności naukowej i gospodarczej państwa problematyka pozycji i formy prawnej, „Prawo Budżetowe Państwa i Samorządu” 2015, nr 4, s. 63-76.

Kmieciak Z., Odwołanie w postępowaniu administracyjnym, Warszawa 2011.

Knysiak-Molczyk H., Kodeks postępowania administracyjnego. Komentarz, Warszawa 2015.

Michta D., Ustawa o instytutach badawczych. Komentarz, Warszawa 2013.

Rybicki Z., S. Piątek, Zarys prawa administracyjnego i nauki administracji, Warszawa 1988.

Stec M (red.), Regionalne izby obrachunkowe. Charakterystyka ustrojowa i komentarz do ustawy, Warszawa 2010.

Woś T. (red.), Postępowanie sadowoadministracyjne, Warszawa 2015.

\section{ADMINISTRATIVE DECISION \\ ON THE REPEAL OF THE RESOLUTION OF SCIENTIFIC COUNCIL OF RESEARCH INSTITUTE}

\section{S u m m a r y}

Research institutes are filled into widely understood science system in Poland. They are organizational units separated organizationally and financially - having legal personality. Activities of an institute is based on the statute and its organs include: director and science council which adopts resolutions in important matters related to institute tasks. The resolutions of science council of research institute are subject of supervision of competent minister who, in the course of supervisory interference can repeal in part or entirely the 
resolution of the council. The supervision on legislative activity of science councils of research institutes is expressed in forms of administrative decision which is a subject to review by means of a reconsideration of the case and by a court-administrative complaint. The only criterion of supervision on science council resolutions of research institutes is the legality - compliance with universally applicable law and the statute of the institute. Legality is also the point of reference during verification of supervisory decisions over the resolutions of scientific councils, whether in administrative procedure or juridical control. In the latter case, the supervisory authority may exercise the right of self-control.

Key words: research institute, supervision, administrative decision

\section{АДМИНИСТРАТИВНОЕ РЕШЕНИЕ КАК ФОРМА ОСУЩЕСТВДЕНИЯ НАДЗОРА НАД РЕШЕНИЯМИ ОРГАНОВ, ВХОДЯЩИХ В СОСТАВ ИССДЕДОВАТЕЛЬСКОГО ИНСТИТУТА}

\section{P е 3 юм е}

Исследовательские институты вписываются в широко понятную систему науки в Польше. Являются организованными отделами организационно и финансово отделенным - которые имеют правосубъъектность. Деятельность института опирается на уставе, же к его органам относятся: директор и научный совет, который поднимает решения в важных делах, связанных с деятельностью института. Решения научного совета исследовательского института подлежат контролю соответствующего министра, который в рамках проведения контроля может отменить частично или полностью решение совета. Контроль над деятельностью по принятию решений научных советов исследовательских институтов совершается в форме административного решения, которое подлежит верификации в порядке повторного разбирательства дела, а также в порядке судебно-административной жалобы. Единственным критерием контродя над постановлениями научных советов исследовательских институтов является легальность - согласно с общеобязательным правом и уставом института. Также легальность явдяется пунктом отнесения при верификации контрольных решений над постановлениями научных советов, то ли в административном порядке, то ли в порядке судебного контроля. В последнем случае орган контроля может воспользоваться правом самоконтроля.

Ключевые слова: исследовательский институт, контродь, административное решение 